\title{
Pengembangan Kompetensi Penelitian Sosial Melalui Pelatihan Statistik Bagi Siswa Madrasah Aliyah Salafiyah Ketegan, Tanggulangin, Kab. Sidoarjo
}

\author{
${ }^{1}$ Imamul Huda Al Siddiq, ${ }^{2}$ Wahyu Djoko Sulistyo, ${ }^{3}$ Alan Sigit Fibrianto \\ ${ }^{1,2,3}$ Universitas Negeri Malang, Indonesia
}

Email: 1'Imamul.huda.fis@um.ac.id, ${ }^{2}$ wahyu.djoko.fis@um.ac.id,

3alan.sigit.fis@um.ac.id

Tersedia Online di
http://www.jurnal.unublitar.ac.id/i
ndex.php/briliant

\begin{tabular}{l}
\hline Sejarah Artikel \\
\hline Diterima pada 16 Oktober 2019 \\
Disetujui pada 10 November 2019 \\
Dipublikasikan pada 29 Februari \\
2020 Hal. 1-9 \\
\hline
\end{tabular}

\begin{tabular}{l}
\hline Kata Kunci: \\
\hline Penelitian sosial; Pengembangan \\
Kompetensi; Statistika sosial \\
\hline DOI:
\end{tabular}

http://dx.doi.org/10.28926/briliant. v3i4.369 perbedaan yang signifikan antara nilai pretest dan nilai posttest. Hasil tersebut menunjukkan bahwa terjadi peningkatan pemahaman peserta terhadap statistika social dasar setelah pelatihan.

\begin{abstract}
Abstrak: Statistika sosial menjadi alat analisa cukup penting dalam penelitian sosial, tertuama pendekatan kuantitatif, namun materi tersebut cukup menjadi momok bagi siswa sekolah menengah atas. Untuk itu, siswa sekolah menengah atas perlu mulai dikenalkan dengan materi penelitian social, diamana statistika dasar diterapkan. Statistika merupakan metode pengolahan data yang berupa angka. Pengetahuan ini penting untuk dipahami oleh para siswa baik saat ini maupun bekal nantinya. Pelatihan ini dilaksanakan atas dasar pertimbangan tersebut. Pelaksaanya meliputi tiga tahapan, yaitu persiapan, pelaksanaan dan evaluasi. Hasil dari kegiatan ini menunjukkan capaian yang signifikan. Hal ini dapat dilihat dari pelaksanaan yang berjalan lancar. Hasil evaluasi dengan membandingkan hasil pretest dan posttest menujukkan hasil bahwa $t$ value $(2,474)$ lebih besar dari t-tabel $(2,228)$ dengan taraf kesalahan sebesar 0,05 , artinya disimpulkan bahwa terdapat
\end{abstract}

\section{PENDAHULUAN}

Struktur kurikulum 2013 yang telah disempurnakan dalam edisi revisi menjadi acuan penyelenggaraan pendidikan nasional (Hasan, 2013). Level sekolah menengah atas khususnya yang program Ilmu Pengetahuan Sosial di dalamnya terdapat materi metodologi penelitian sosial. Materi tersebut seringkali dianggap sebagai salah satu yang sulit dalam pembelajaran sosiologi (Rohmat, 2018). Dalam kurikulum 2013 sosiologi merupakan sajian mata pelajaran wajib yang harus diambil oleh para siswa program IPS. Sebagai ilmu yang memberi bekal pengetahuan sosial implikatif kepada siswa maka keberadaan mata pelajaran sosiologi tidak dapat dikesampingkan. Selain memberikan pengetahuan, secara tidak langsung mata pelajaran ini bersama dengan mata pelajaran yang lainnya juga mengasah kemampuan untuk bersikap bagi para siswa ketika hidup di tengah-tengah masyarakat (Hanum \& Si, 2011; Sulistyo, 2019). Kurikulum yang mengintegrasikan antara spiritualitas, afektif, kognitif, dan psikomotorik ini mengadopsi seluruh penguatan sikap di dalam aspek kognitif (Putri, 2011) . 
Aspek kognitif yang menjadi salah satu penekanan utama dalam mata pelajaran sosiologi adalah materi metode penelitian sosial. Berdasarkan pada survey yang dilakukan oleh tim di lapangan bahwa di kurikulum 2013 edisi revisi, pada jenjang sekolah menengah, materi penelitian sosial diberikan pada tahun pertama proses pembelajaran atau ketika siswa menginjak kelas X. Materi metode penelitian sosial diberikan di awal pembelajaran untuk memberikan bekal kepada siswa ketika mendapatkan materi lainnya, mereka memiliki bekal untuk melihat realitas sesungguhnya sesuai dengan topik yang sedang dipelajari. Siswa dalam mata pelajaran ini diberi bekal untuk melakukan penelitian lapangan sebagai alat untuk melihat realitas sosial yang ada. Tidak hanya pembelajaran secara langsung di kelas, pembelajaran juga bisa dilakukan melalui observasi lapangan (Fägerstam, 2012; Samsudin, 2016).

Dalam penelitian sosial yang berlandaskan pada data-data empiris, terdapat dua arus utama pendekatan penelitian yang sudah menjadi rahasia umum para akademisi, yaitu pendekatan kuantitatif dan pendekatan kualitatif. Dua pendekatan ini memiliki asumsi berbeda satu dengan yang lainnya namun mereka dapat saling mengisi. Hanya saja, banyak siswa yang belum memahai secara utuh esensi masing-masing penelitian dan bagaimana cara untuk menganalisisnya. Terlebih lagi untuk pendekatan kuantitatif dimana menempatkan bentuk data berupa angka (Bernard \& Bernard, 2013; Sugiyono, 2008). Data berupa angka dalam penelitian perlu melewati serangkaian tahapan secara metodologis dari penyajian data hingga penarikan kesimpulan. Serangkaian metodologis itulah yang dikenal dengan statistika dasar (Nugroho, 2008). Inilah yang menjadi permasalahan utama bagi siswa sekolah menengah bahkan mahasiswa di perguruan tinggi sekalipun khususnya program IPS jika sudah dihadapkan pada data berupa pengolahan angka, mereka cenderung merasa kesulitan (Suminta \& Sayekti, 2017). Meskipun kenyataan seperti itu, dan meski perkembangan digitalisasi dan aplikasi ilmu pengetahuan menjadikan transformasi pengetahuan semakin mudah (Veletsianos \& Kimmons, 2016), namun pengetahuan mengenai statistika ini tetaplah menjadi bekal penting bagi mereka baik selama menjadi siswa atau nanti jika melanjutkan pada jenjang bangku perkuliahan.

Pengetahuan mengenai statistika sangatlah penting bagi para siswa. Oleh karena itu dari permasalahan yang diuraikan di atas perlu diadakan kegiatan pelatihan statistika (Dhewy, 2018). Target yang menjadi sasaran dalam pelatiahn ini adalah para siswa sekolah menengah atas. Tujuan dari kegiatan pengabian ini adalah memberikan wawasan kepada mereka tentang statistika secara praktis dan efektif. Selain itu juga memberikan bekal bagi mereka jika nantinya melanjutkan ke jenjang pendidikan yang lebih tinggi lagi. Sekolah yang dipilih sebagai objek kegiatan pengabdian pelatihan statistika ini adalah Madrasah Aliyah Swasta (mas) salafiyah ketegan-tanggulangin kab. Sidoarjo. Dipilihnya sekolah tersebut berdasarkan beberapa pertimbangan, diantaranya adalah : sekolah menengah atas ini bercorak madrasah yang mempunyai historis pada awalnya adalah sebuah pondok pesantren yang berkembang menjadi sekolah, sehingga penekanan ilmu keagamaan lebih kuat dibandingkan ilmu umum lainya. Yang ke dua berdasarkan survey yang dilakukan pada kegiatan pendahuluan bahwa sebagian siswa di sekolah ini kurang bahkan tidak memahami pengetahuan mengenai statistika. Berdasarkan pertimbangan di atas maka dipilihlah sekolah ini menjadi objek pengabdian. Kegiatan pengabdian ini diharapkan bisa bermanfaat bagi eskalasi 
kemampuan siswa kelas XII Masdrasah Aliyah Swasta (MAS) dalam mengimplementasikan statistik sosial dasar pada penelitian sosial. Kegiatan pengabdian yang dilaksanakan oleh tim di sekolah ini merupakan upaya yang bisa dilakukan dalam memberikan pemahaman kepada guru dan siswa. Bentuk dari kegiatan yang dilakukan dengan memberikan pelatihan metode penelitian sosial terutama implementasi statistika sosial dasar dalam penelitian. Pelatihan ini bukan menggantikan materi-materi penelitian sosial yang telah ada dalam pembelajaran mata pelajaran sosiologi di SMA/MA. Namun pelatihan ini dilaksanakan sebagai sarana untuk membantu siswa semakin memahami esensi dari penelitian sosial.

\section{METODE}

Pengabdian kepada masyarakat ini dilakukan dengan cara menerapkan metode pembelajaran langsung dengan melalui 3 tahapan yaitu:

Tahap pertama (persiapan): pada tahapan awal ini kegiatan yang dilakukan adalah melakukan survey dan observasi kesekolah sasaran. Survey dan observasi dilakukan sebagai langkah awal dalam penelitian untuk mengetahui secara jelas tentang objek penelitian/sasaran (Hasanah, 2017; Samsudin, 2016). Membicarakan tentang tujuan pengabdian dan melakukan analisis kebutuhan akan pengetahuan mengenai statistika kepada baik guru maupun siswa melalui kegiatan wawancara (Soegijono \& KR, 1993). Setelah terjadi kesepaktan antara pihak sekolah dengan tim pengabdian selanjutnya melakukan koordinasi secara intentsif hingga tiba pada waktu pelaksanaan sesuai yang disepakati.

Tahap kedua (Pelaksanaan): Pada tahapan ini merupakan tahapan inti, dimana kegiatan pelatihan diimplementasikan dengan cara pembelajaran langsung, yang didefinisikan sebagai model pembelajaran yang mengaplikasikan hubungan langsung antara guru dan murid atau antara fasilitator dan peserta. Dalam pembelajaran ini fasilitator mentransformasikan informasi atau keterampilan secara langsung kepada peserta didik. Model pembelajaran langsung juga diartikan sebagai model pembelajaran yang dirancang khusus untuk menunjang proses belajar siswa yang berkaitan dengan pengetahuan deklaratif dan pengetahuan yang terstruktur dengan baik (Panjaitan, 2017; Widyantini, 2012). Proses pembelajaran langsung meliputi lima fase yang sangat penting. Fase tersebut antara lain menyampaikan tujuan dan mempersiapkan siswa; mendemonstrasikan pengetahuan dan keterampilan; membimbing pelatihan; mengecek pemahaman dan memberikan umpan balik; dan fase terakhir memberikan kesempatan untuk pelatihan lanjutan dan penerapan (Sakti, Puspasari, \& Risdianto, 2012). Sebelum dilaksanakan penyampaian materi statistika oleh fasilitator sebelumnya dilakukan kegiatan untuk mengukur kemampuan dan pengetahuan dasar peserta melalui kegiatan pretest. Selanjutnya dilaksanakan pembelajaran langsung pelatihan statistika.

Tahap ketiga (Evaluasi): pada tahapan ketiaga atau tahap akhir dalam pelaksanaan pengabdian ini adalah dilakukan evaluasi. Kegiatan evaluasi dilakukan dengan menyebarkan angket untuk mengetahui tingkat kepuasan peserta terhadap pelatihan yang dilaksanakan. Selain penyebaran angket untuk penilaian terhadap efektifitas kegiatan pengabdian, para peserta juga mengisi lembar post test untuk mengukur ketercapaian pengetahuan kognitif mereka menganai statistika sesuai yang direncanakan di awal. Hasil dari evaluasi inilah 
yang menjadi dasar penarikan kesimpulan dalam mengukur keberhasilan kegiatan pengabdian ini (Arifin, 2009).

\section{HASIL}

Uraian mengenai hasil pengabdian dideskripsikan dalam pembahasan di bawah ini yang terbagi menjadi tiga bahasan, yaitu :

a. Persiapan pelaksanaan pelatihan

Kegiatan pertama sebelum dilaksanakannya pengabdian kepada masyaraat ini adalah survey dan berkomunikasi kepada sasaran pengabdian, yakni MA Salafiyah Al Hidayah Ketegan Tanggulangin Sidoarjo. Komunukasi dilakukan untuk memberikan kejelasan kepada pelaksana pengabdian kapan pengabdian bisa dilaksanakan. Selain itu, komunikasi awal bertujuan untuk memberikan gambaran kepada pelaksana pengabdian teknik pemberian materi sekaligus dapat mendengarkan kebutuhan kelas berkaitan dengan pelatihan statistik sosial dasar ini.

Selain itu, pelaksana pengabdian kepada masyarakat juga melakukan koordinasi internal untuk menentukan salah satunya adalah materi pelatihan. Materi pelatihan statistik sosial deskriptif yang terdiri dari distribusi frekuensi, tendensi sentral.

\section{b. Pelaksanaan pelatihan}

Pelatihan implementasi statistika sosial dasar bagi MAS Salafiyah Ketegan Tanggulangin, Sidoarjo dilaksanakan pada tanggal 24-25 agustus 2019. Untuk hari pertama yaitu pemyampaian materi statistika oleh tiga fasilitator yang merupakan anggota tim pengabdian, yaitu : Wahyu Djoko Sulistyo, M.Pd, Imamul Huda Al Sidiq, M. Sosio dan Alan Sigit Fibrianto, S.Pd., M. Sos. Ketiganya merupakan dosen pengampu mata kuliah statistik di program studi masing- masing. Hari kedua pelatiahn untuk implementasi atau praktik implementasi statistika dasar dengan melakukan penyajian data dalam bentuk tabel, diagram dan grafik.

Peserta kegiatan terbagi kedalam dua kelas untuk peserta laki-laki dan perempuan yang dipisah menjadi dua kelas. Kelas pertama untuk peserta laki-laki berjumlah 13 siswa bertempat di ruang kelas XII madrasah laki-laki. peserta kedua untuk peserta perempuan berjumlah 22 siswa bertempat di lantai dua masjid madrasah.

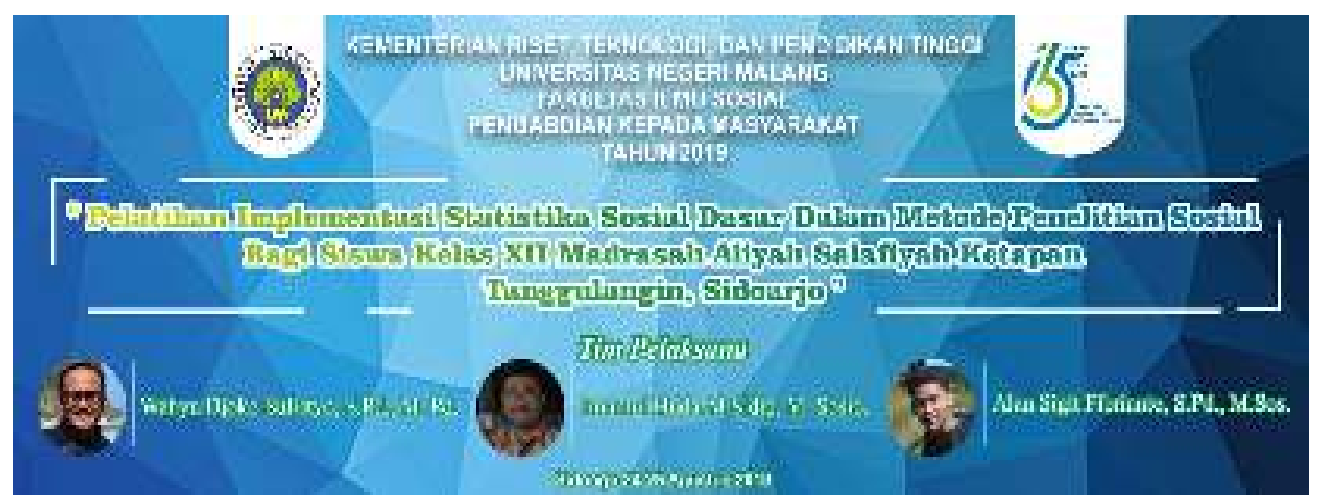

Gambar 1. Banner Kegiatan Pengabdian 
Deskripsi pelaksanaan kegiatan :

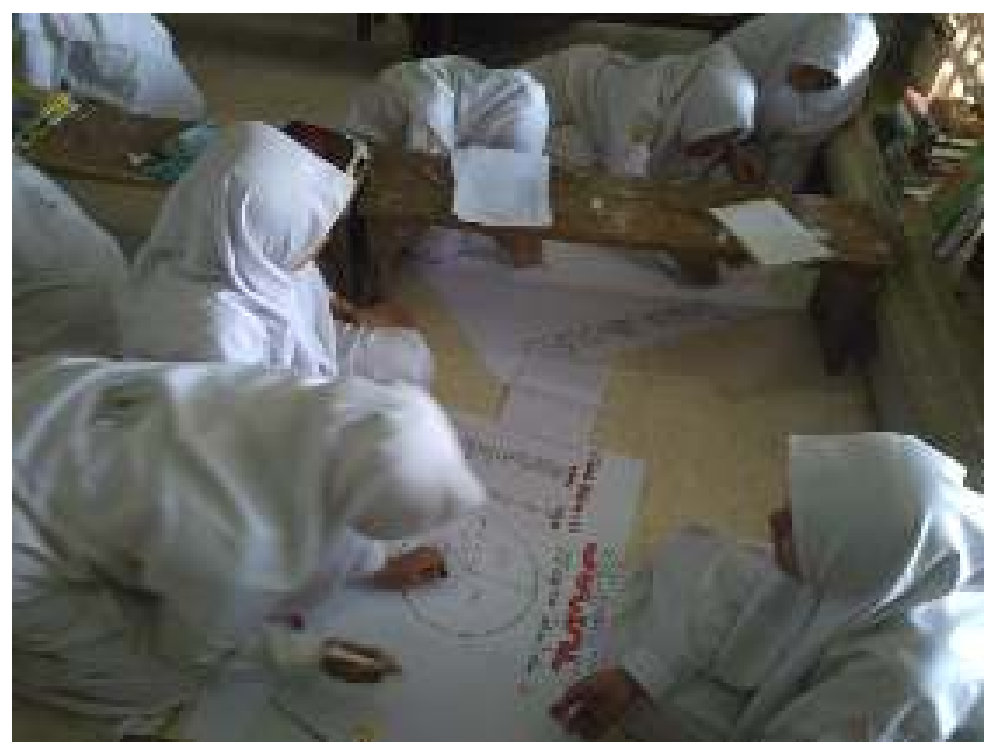

Gambar 2. Praktik penyajian data oleh peserta pelatihan (Dok. Pribadi)

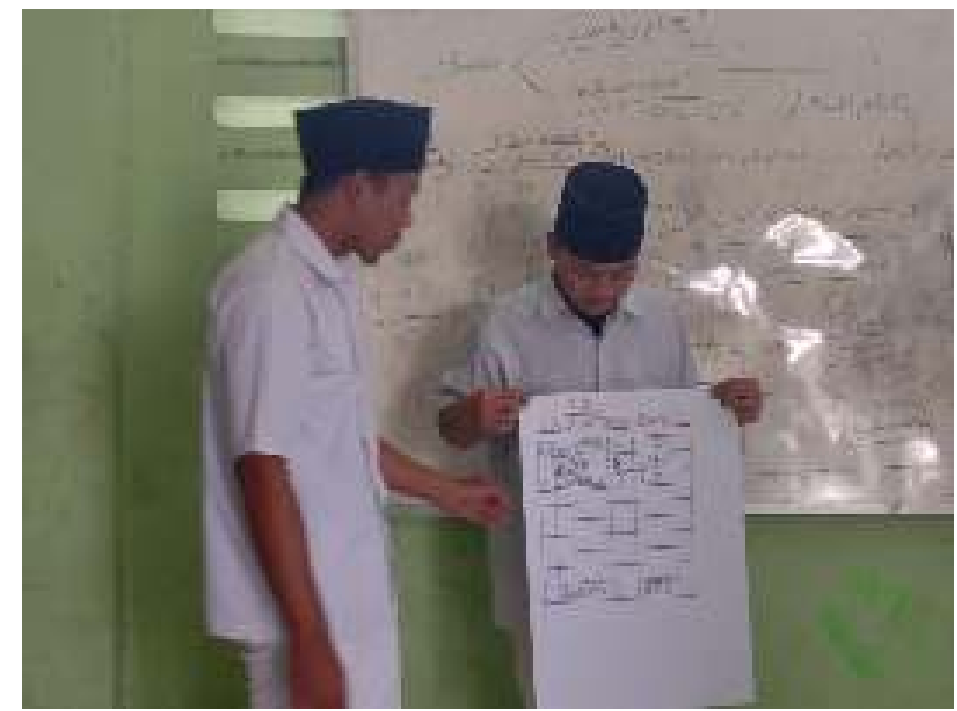

Gambar 3: Praktek penyajian data dan presentasi oleh peserta pelatihan (Dok. Pribadi)

\section{PEMBAHASAN}

\section{a. Evaluasi}

\section{Analisis statistika hasil pretest dan postest}

Sebelum dilaksanakannya pelatihan statistik sosial dasar ini pelaksana pengabdian membagikan sejumlah item pertanyaan sebagai instrumen pretest. Item pertanyaan berjumlah 11 (sebelas) pertanyaan dalam bentuk pilihan ganda. Diskripsi pertanyaan yang dihadirkan pada pretest dapat dilihat sebagaimana tabel di bawah ini: 
Tabel 1: Presentase capaian pre-test dan post-test

\begin{tabular}{|c|c|c|c|}
\hline \multirow{2}{*}{ NO. } & \multirow{2}{*}{ PERTANYAAN } & \multicolumn{2}{|c|}{ Presentase Capaian } \\
\hline & & Pre-test & Post-test \\
\hline 1 & $\begin{array}{l}\text { Penelitian yang menggunakan statistik sebagai alat } \\
\text { analisisnya adalah penelitian... }\end{array}$ & 17 & 92 \\
\hline 2 & $\begin{array}{l}\text { Cara berpikir yang mendahulukan hal yang umum dari pada } \\
\text { hal khusus adalah cara berpikir... }\end{array}$ & 9 & 100 \\
\hline 3 & $\begin{array}{l}\text { Salah satu ciri ilmu sosial adalah berkembang seara dinamis, } \\
\text { hal ini menandakan bahwa... }\end{array}$ & 3 & 23 \\
\hline 4 & Konsep yang dapat memiliki sebuah variasi nilai adalah... & 51 & 92 \\
\hline 5 & $\begin{array}{l}\text { Pernyataan yang masih butuh dibuktikan kembali } \\
\text { kebenarannya disebut dengan... }\end{array}$ & 17 & 46 \\
\hline 6 & $\begin{array}{l}\text { Pernyataan yang menunjukkan penjelasan atas fakta atau } \\
\text { realitas, yang dibangun melalui penelitian disebut... }\end{array}$ & 29 & 38 \\
\hline 7 & $\begin{array}{l}\text { Hipotesis yang digunakan sebagai alat untuk menarik sebuah } \\
\text { kesimpulan pada proses statistik sosial disebut dengan... }\end{array}$ & 23 & 85 \\
\hline 8 & $\begin{array}{l}\text { Hipotesis kerja diterima dalam proses statistik harus } \\
\text { memenuhi syarat bahwa... }\end{array}$ & 51 & 46 \\
\hline 9 & $\begin{array}{l}\text { Data yang sering muncul dalam suatu kelompok data disebut } \\
\text { dengan... }\end{array}$ & 66 & 46 \\
\hline 10 & $\begin{array}{l}\text { Perhatikan angka ini: } 5,6,2,4,5 \text {, mean dari data tersebut } \\
\text { adalah... }\end{array}$ & 20 & 8 \\
\hline 11 & $\begin{array}{l}\text { Perhatikan angka ini 5,6,2,4,5, median dari data tersebut } \\
\text { adalah... }\end{array}$ & 37 & 46 \\
\hline & Rata-rata & 29,4 & 56,5 \\
\hline
\end{tabular}

Tabel di atas menunjukkan hasil pre test dan post test atas kemampuan statistik sosial dasar para peserta pelatihan atau siswa. Rata-rata capaian kemampuan siswa sebelum dilakukannya pelatihan ini adalah sebesar 29,4\%. Dari seluruh total kemampuan yang harus dikuasai berkaitan dengan statistika sosial dasar, peserta hanya mampu mencapai kemampuan sebesar 29,4\%. Setelah dilaksanakannya pelatihan ini kemampuan peserta mengalami peningkatan menjadi 56,5\%. Capaian ini menandakan bahwa pelatihan yang telah dilakukan memberikan pengaruh positif terhadap kemampuan peserta meski belum mencapai angka yang cukup tinggi. Namun untuk mengetahui apakah pelatihan ini memiliki pengaruh yang signifikan perlu dilakukan uji komparasi dua sampel berpasangan dengan menggunakan uji t.

\section{Efektifitas Pelatihan: Sebuah Uji Komparasi}

Untuk mengetahui apakah pelatihan statistik sosial dasar pada siswa Madrasah Aliyah Salafiyah memiki pengaruh yang signifikan terhadap peningkatan kompetensi siswa, maka uji komparasi dengan uji t perlu untuk dilakukan. Di bawah ini merupakan hasil uji t yang telah dilakukan: 
Tabel 2: Nilai uji statistik inferensial

\begin{tabular}{|lc|}
\hline Mean Pretest & 29,4 \\
Mean Posttest & 56,5 \\
Taraf kesalahan & 0,05 \\
t-value & 2,474 \\
t-tabel 2 tailed & 2,228 \\
\hline
\end{tabular}

Tabel di atas menunjukkan bahwa $\mathrm{t}$ value lebih besar dari pada $\mathrm{t}$ tabel dengan taraf kesalahan sebesar 0,05, maka Hipotesis Nol yang menyatakan bahwa tidak ada perbedaan antara pre test dan post test kemampuan statistik sosial dasar siswa ditolak. Dengan demikian maka dapat disebutkan bahwa antara pre test dan post test terdapat perbedaan yang siginifikan sehingga pelatihan yang telah dilakukan oleh tim pelaksana pengabdian adalah siginifikan. Pelatihan dapat meningkatkan kemampuan siswa dalam statistik sosial dasar secara efektif.

Berbagai upaya pelatihan untuk meningkatkan kompetensi tertentu tidak semuanya terbukti memiliki hasil yang signifikan. Pelatihan Perawatan Diri terhadap Dukungan Emosional dan Instrumental Keluarga Penderita Kusta yang dilaksanakan oleh Wulandari dkk (2011) membuktikan hal demikian. Pelatihan yang dilakukan terbukti memiliki pengaruh yang signifikan terhadap dukungan instrumental keluarga, namun tidak signifikan terhadap dukungan emosional. Pelatihan yang dilakukan oleh Fauziarti \& Soedarsono (2014) tentang kurikulum pendidikan anak usia dini juga terbukti efektif dalam mengingkatkan kompetensi peserta. Dengan demikian materi dan metode pelatihan cukup menentukan apakah pelatihan yang dilaksanakan dapat berjalan efektif dengan memberikan manfaat yang signifikan bagi peserta atau tidak.

\section{KESIMPULAN}

Serangkaian kegiatan pengabdian dengan judul kegiatan pelatihan implementasi statistika sosial dasar dalam metode penelitian sosial bagi siswa kelas xii madrasah aliyah swasta (mas) salafiyah ketegan-tanggulangin kab. sidoarjo telah berjalan dengan baik. melalui tiga langkah kegiatan mulai dari persiapan, pelaksanaan hingga evaluasi. hasil yang didapatkan dari kegiatan pengabdian ini bagi peserta adalah bertambahnya pengetahuan mengenai konsep dasar statistika dan manfaatnya secara langsung dalam penelitian sosial. hal ini dapat dilihat dari perbandingan t-test antara hasil pretest dan posttest yang menunjukkan nilai uji $\mathrm{t}$ lebih besar dari pada nilai t tabel yang artinya adalah terdapat perbedaan yang signifikan antara pre test dan post test sehingg pelatihan tersebut dapat dikatakan memiliki manfaat yang signifikan.

\section{SARAN}

Proses pengabdian masyarakat berbasis hasil penelitian dewasa ini menjadi tren dalam proses tri dharma perguruan tinggi. Oleh karena itu ke depan, penelitian tentang peningkatan kompetensi statistik sosial di kalangan siswa/mahasiswa ilmu sosial perlu dipertajam dengan mempertimbangkan 
variabel independent lainnya agar pengabdian yang dilaksanakan dengan dasar hasil penelitian menjadi lebih tajam dan tepat sasaran.

\section{DAFTAR RUJUKAN}

Arifin, Z. (2009). Evaluasi pembelajaran (Vol. 8). Bandung: Remaja Rosdakarya.

Bernard, H. R., \& Bernard, H. R. (2013). Social research methods: Qualitative and quantitative approaches. Sage.

Dhewy, R. C. (2018). Pelatihan Dasar-dasar Statistika dengan Menggunakan Aplikasi Microsoft Excel di Sdn Pamotan II Kecamatan Porong. JURNAL PADI (Pengabdian Masyarakat Dosen Indonesia), 1(1), 36-40.

Fägerstam, E. (2012). Space and Place: Perspectives on outdoor teaching and learning (PhD Thesis). Linköping University Electronic Press.

Fauziarti, B. F., \& Soedarsono, Fx. (2014). Efektivitas Pelatihan Kurikulum Pendidikan Anak Usia Dini di Kecamatan Grabag. Jurnal Pendidikan dan $\begin{array}{lll}\text { Pemberdayaan } & \text { Masyarakat, } & 174 .\end{array}$ https://doi.org/10.21831/jppm.v1i2.2687

Hanum, F., \& Si, M. (2011). Konsep, Materi dan Pembelajaran Sosiologi. Makalah Disampaikan Pada Seminar Regional: Pembelajaran Dan Pendidikan Karak-Ter Mata Pelajaran Sosiologi, Yang Diselenggarakan Jurusan Sosiologi Dan Antropologi Universitas Negeri Surakarta, 27.

Hasan, H. S. (2013). Kurikulum 2013. Makalah Seminar Nasional, UNJ.

Hasanah, H. (2017). Teknik-teknik observasi (sebuah alternatif metode pengumpulan data kualitatif ilmu-ilmu sosial). At-Taqaddum, 8(1), 21-46.

Nugroho, S. (2008). Dasar Dasar Metode Statistika. Grasindo.

Panjaitan, D. J. (2017). Meningkatkan Hasil Belajar Siswa Dengan Metode Pembelajaran Langsung. JURNAL MATHEMATIC PAEDAGOGIC, l(1), 83-90.

Putri, N. A. (2011). Penanaman Nilai-Nilai Pendidikan Karakter Melalui Mata Pelajaran Sosiologi. Komunitas: International Journal Of Indonesian Society and Culture, 3(2).

Rohmat, Z. (2018). Problematika Pendidik Sosiologi Antropologi Di Masyarakat Multikultural. Habitus: Jurnal Pendidikan, Sosiologi, Dan Antropologi, 2(1), 151-172.

Sakti, I., Puspasari, Y. M., \& Risdianto, E. (2012). Pengaruh Model Pembelajaran Langsung (Direct Instruction) Melalui Media Animasi Berbasis Macromedia Flash Terhadap Minat Belajar Dan Pemahaman Konsep Fisika Siswa Di SMA Plus Negeri 7 Kota Bengkulu. Exacta, X(1), 1-10. https://doi.org/10.1073/pnas.1411514112

Samsudin, M. D. I. (2016). Pengaruh Pembelajaran Model Observasi Lapangan (OUTDOOR STUDY) dan Pembelajaran Inquiry terhadap Hasil Belajar Mata Pelajaran Sosiologi Siswa IPS SMA Negeri 3 Probolinggo. Jurnal Penelitian Dan Pendidikan IPS (JPPI), 10(2).

Soegijono, M. S., \& KR, D. (1993). Wawancara Sebagai Salah Satu Metode Pengumpulan Data. Media Penelitian Dan Pengembangan Kesehatan, $3(1)$.

Sugiyono. (2008). Metode penelitian pendidikan: (pendekatan kuantitatif, kualitatif dan $R \& D)$. Alfabeta. 
Sulistyo, W. D. (2019). MENGGUGAH SENSITIVITAS SOSIAL MAHASISWA MELALUI IMPLEMENTASI PRAKSIS SOSIAL. Jurnal Sosiologi Pendidikan Humanis, 4(1), 38-46.

Suminta, R. R., \& Sayekti, F. P. (2017). Kecemasan Statistik Ditinjau dari Jenis Kelamin. Quality, 5(1), 140-154.

Veletsianos, G., \& Kimmons, R. (2016). Scholars in an increasingly open and digital world: How do education professors and students use Twitter? The Internet and Higher Education, 30, 1-10. https://doi.org/10.1016/j.iheduc.2016.02.002

Widyantini, T. (2012). Penerapan model pembelajaran langsung dalam mata pelajaran matematika SMP/MTs. Pusat Pengembangan Dan Pemberdayaan Pendidik Dan Tenaga Kependidikan (PPPPTK) Matematika.

Wulandari, L., Suswardany, D. L., \& Firnawati, A. F. (2011). Efektivitas Pelatihan Perawatan Diri terhadap Dukungan Emosional dan Instrumental Keluarga Penderita Kusta. Jurnal Keperawatan Soedirman, 6, 10. 